\title{
MODERNE SCHRIFTBESCHOUWING
}

\author{
Prof. dr. C. Trimp (Kampen)
}

Wij willen ons konfronteren met enige moderne trends in de theologie op het punt van de schriftbeschouwing. Daarbij concentreren wij ons vooral op het bekende Nederlandse rapport uit 1981: God met ons.

Ik zou $u$ willen wijzen op vijf punten:

1. Een van de achtergronden van de moderne schriftbeschouwing is de stelling dat de mens als zodanig bondgenoot van God is. Menszijn is bondgenoot-zijn.

Hiermee hangt natuurlijk een andere stelling samen: Gol is als zodanig partner-God.

Wat gebeurt hier nu eigenlijk? Hier worden enige resultaten van modern-anthropologisch inzicht geprojekteerd op de verhouding tot God en in God zelf. De mens is mede-mens; hij leeft als een relationeel wezen in een ik-jij-verhouding. Slechts in de ontmoeting met de medemens kan de waarheid oplichten.

Deze denkstijl is een reaktie op het idealisme van de vorige eeuw. Door de invloed van de joodse wijsgeer Martin Buber is deze stijl tot grote bloei gekomen. Wij zouden kunnen spreken van het “ontmoetings-denken'. Het is de achtergrond van het rapport over het schriftgezag dat binnen de Ned. hervormde kerk in 1967 is verschenen onder de titel Klare Wijn.

Maar wij treffen deze denkstijl ook b.v. aan in de dogmatiek van H. Berkhof, die met behulp van de partner-idee de leer van de drieeenheid van Gorl meent te kunnen vervangen: De partner-God vindt in Jezus Christus dé representant van de mens en de kracht van deze God en zijn bondgenoot is Heilige Geest.

2. Een tweede motief in de moderne theologie betreft de openbaring. Openbaring is niet het soevereine Woord en de soevereine daad van God ("van boven naar beneden"). Openbaring is een kwalifikatie van de menselijke ervaring - een diepte-dimensie in de menselijke ervaring. Bepaalde feiten binnen de menselijke ervaringswereld krijgen een transparantie, waardoor wij in die feiten een overmacht; een stem, een hogere leiding gaan ontdekken.

Wanneer je die ervaringen schriftelijk vastlegt, ontstaan er dokumenten waarin de mens zijn beleving vastlegt. En als je al die dokumenten bundelt in éen band, krijg je een boek, dat de christenen de bijbel noemen.

Maar die bijbel is een kultureel produkt. Daarin staan feiten geboekstaafd plus de menselijke beleving en interpretatie van die feiten. En het onder-woorden-brengen daarvan is gebeurd naar de gewoonten en met de middelen van die eigentijdse kultuur.

Had b.v. Israel het literaire genre van de psychologische roman gekend, dan zou de bijbel er wel anders hebben uitgezien dan thans het geval is. Dan zou daarin veel meer innerlijke beleving en ervaring onder woorden zijn gebracht. 
Maar hoe ging dat vroeger? Wanneer men grote emoties wilde weergeven deed men dat door de feiten enorm te vergroten. Een psychische schok werd zó weergegeven, dat de eigenlijke gebeurtenis werd 'uit-vergroot', zoals we dat bij de fotografie noemen. Bij die uitvergroting hoort ook, dat wij, mensen, de naam van God verbinden aan bepaalde feiten als b.v. de uittocht uit Egypte. In de bijbel lezen we, dai God zich niet schaamt zijn naam te verbinden aan bepaalde mensen en hun levensgeschiedenis (Hebr. 11:16). Maar in de moderne theologie worden de zaken net andersom gesteld: wij schamen ons niet om Gods naam aan onze ervaringen te verbinden. De feiten worden door óns benoemd.

3. Het rapport God met ons werkt op dezelfde manier. De titel van dit rapport bevat inderdaad het oerwoord van het verbond, maar het verhaal is totial anders gericht dan het verhaal van de bijbel over Gods verbond. Het getuigenis van Gods openbaringsaktiviteit wordt tot verslag van menselijke ervaring, waarbij mensen het 'vergrootglas' hebben gehanteerd en - net als in de beeldende kunst tot opzettelijke vertekeningen zijn gekomen $(14,83,79)$.

Wij, vandaag, worden daardoor geïnspireerd tot óns verslag van onze ervaringen. Maar het vroegere verslag moge dan inspirerend voor ons zijn, het is niet canoniek d.w.z. het bevat geen normatieve waarheid voor alle latere geslachten.

4. Dit betoog wordt gevoed door een filosofische beschouwing over de waarheid als 'relationele waarheid'. Wat betekent dit kernbegrip in het rapport? Het betekent niet dat er een relatie moet zijn, waarbinnen de waarheid geopenbaard wordt of funktioneert. Dat zou immers een tamelijk irrelevante konstatering zijn.

Naar mijn inzicht betekent 'relationele waarheid' twee dingen:

1. Waarheid wordt slechts openbaar binnen de aardse relaties, waarin de mens funktioneert;

2. Waarheid is een gebeuren, dat nooit tot stilstand komt.

Ad. 1. Waarheid - aldus het rapport - tekent zich steeds af binnen een relatie, binnen de betrokkenheid van de mens op iets anders (13). De mens is een relationeel wezen; hij leeft en funktioneert permanent in allerlei betrekkingen, b.v. met zijn omgeving, zijn medemensen, de gebeurtenissen.

$\mathrm{Nu}$ gaat het erom, dat wij de openbaring van God niet uitlichten uit die menselijke relaties, maar juist dáárbinnen zien oplichten Wij kunnen dit het beste illustreren met het voorbeeld, dat de auteur van deze term, dr. C. A. van Peursen, zelf heeft gebruikt in een geschrift uit het jaar 1967 (Hij is het weer! p. 8 vv.).

Wij lezen in de Bijbel: "De Here nu zei tot Abram: Ga uit uw land en uit uw maagschap en uit uws vaders huis naar het land dat Ik u wijzen zal" (Gen 12:1). Maar dit woord betekent niet dat 4 bram God al kende en Hem in zijn spreken herkende. Het betekent sok niet, dat in Abrams leven deze God plotseling binnenkwam met een hemelse stem. Want dat zou toch wel een zeer vreemde ervaring zijn geweest - een buitengewone of metafysische realiteit.

"Die oude, bijbelse figuren hadden geen persoonlijke telefoon- 
lijn waardoorheen geen geruis, maar de zuivere stem van God vernomen word een telefoonlijn die de moderne mens mist".

Nee, wij mreten het ons zo voorstellen, dat in de gebeurtenissen en ontmoetingen van alle dag het woordje 'God' langzamerhand zijn unieke betekenis kreeg. In het dagelijkse leven begon dit woordje te funktioneren als een Naam, die zich aftekende in de direkt gegeven werkelijkheid.

Waarom vertrok Abram dus naar het land dat God hem wijzen zou? Niet vanwege een duidelijk horen van een boven-aardse stem.

Het proces begon met een "vreemd vermoeden" bij Abram dat er ook andere mogelijkheden waren van godsverering dan die Abram tot nu toe in praktijk had gebracht. En dat hing bovendien samen met een situatie van 'onbevredigd-zijn' bij Abram met zijn milieu en levensomstandigheden.

Abram emigreert dus - op eigen initiatief. Het wordt een soort 'grote trek'. Hij gaat op zoek naar nieuwe weidegronden voor zijn kudden en hij had het vermoeden, dat een godheid met hem zou meegaan - een godheid die niet aan én vaste plaats gebonden is.

Toen deze emigratie eenmaal goed gelukt was, schreef eeuwen later een bijbelschrijver: 'En de Here sprak tot Abram'.

Maar wij begrijpen, dat die openbaring omhoog gekomen is uit een mysterieuze aanwezigheid van een nieuwe God in de gewone gebeurtenissen van het leven. De herkenning van die nieuwe God kan men achter af noemen 'openbaring van God' Maar dit woord 'openbaring' is een predikaat van menselijke, relationele ervaring. 'Openbaring' is immers niet een meteoorsteen, die uit een andere wereld op aarde neerploft (15).

Ad 2. In verband hiermee kunnen wij nu ook verstaan, dat 'waarheid' een gebeuren aangeeft, dat nooit tot stilstand zal komen.

Wij horen het rapport spreken over 'de nooit afgesloten geschiedenis van het tot openbaring komen van de waarheid' (15). Die geschiedenis wordt ook, met een duistere term, genoemd 'het waarheidsgebeuren van God' (16).

Immers, de mens funktioneert dagelijks in zijn betrokkenheid op de geschapen werkelijkheid.

De mens ontdekt. in de dingen om zich heen (schepping), in de gebeurtenissen van mens en wereld (geschiedenis), de verhalen en spreuken die uit een oude traditie tot hem komen (bijbel) een derde dimensie: Gods stem, Gods aanwezigheid, Gods overmacht. Dat noemen wij dan 'openbaring'. Maar dan wel een openbaring, die tegelijk de menselijke beleving en interpretatie in zich bevat en voortdurend door de mens wordl geherinterpreteerd met het oog op zijn aktuele situatie.

Op deze wijze denkt men te kunnen ontkomen aan het gevaar van het subjektivisme en het objektivisme met betrekking tot de waarheid Het subjektivisme wordt bestreden door de idee, dat waarheid slechts tot stand komt in de betrokkenheid van de mens op iets anders; het objektivisme wordt tegengegaan door de nadruk die men legt op de menselijke waarneming en interpretatie. 
Waarheid is een zaak van onafgebroken wisselwerking tussen waarneming en theorievorming (11). Waarheid is niet louter de schat in de akker (dat zol objektivisme zijn). Waarheid is de schat in de akker plus ons zoeken daarnaar en ons vinden ervan.

En als we de schat dan gevonden hebben, hebben we dan de waarheid? Nee, dan moeten wij opnieuw gaan zoeken want de onafgebroken wisselwerking moet in stand blijven.

Nooit zullen wij het onbeschrijfelijke vatten in onze woorden geen taal heeft daar de juiste woorden voor; de bijbeltaal niet en onze taal niet $(60)$. Steeds moeten de woorden voor ons weer waarheid worden en gezag krijgen. Wij blijven interpreteren, herinterpreteren en aktualiseren; anders zouden wij buiten de geschiedenis gaan staan en de waarheid buiten de geschiedenis plaatsen $(62,75$ vv., 17). Vandaar de centrale stelling van het rapport:

De waarheid van God is er niet zonder de inzet van mensen; pas als mensentongen in beweging komen, is de openbaring van God er. Onze persoonlijke inzet blijkt deel uit te maken van de op ons toekomende waarheid. Ook de diepste waarheid komt pas tot uiting in de volledige inzet van de mens, om zo als overmacht aan de dag te treden De Heilige Geest is de manifestatie van een vreemde Overmacht samen met de menselijke herkenning en benoeming ervan (13-15). Zo gaat het met óns en zó ging het met de bijbelschrijuers (57). De bijbel is een momentopname van de geloofsinterpretatie en deze is erop uit om voortdurend door latere geslachten geherinterpreteerd te worden.

5. Ik wijs op enige konsekwenties van dit inzicht.

(1) God kan alleen maar God-met-ons zijn. En als wij niet met God zijn, verstomt de waarheid in de wereld.

(2) Waarheid is een gebeuren, een proces - een kommunikatief proces dat in de plaats komt van de omgang in het verbond.

(3) Wie waarheid onafhankelijk maakt van de mens, maakt de bijbel tot een meteoriet (15). Onder dát oordeel valt de gereformeerde leer omtrent de Heilige Schrift. Meteoriet of mensenwerk dat wordt het dilemma, dat men ons opdringt.

(4) De wetenschap - filosofie en theologie - is de bewaker en stimulator van het eindeloze proces van zoeken, vinden, interpreteren.

(5) Dit heeft o.m. tot gevolg, dat de bijbelverhalen over schepping en zondeval geen historisch betrouwbare informatie bieden en ons niet een chronologische volgorde in de beschrijving van geschiedenis presenteren. $W$ ij moeten niet meer vragen naar het hoe, maar wij moeten oog hebben voor het raadsel, dat iedere gelovige moet kwellen, nl. dat de mens vanaf het begin zijn plicht tegenover God heeft verzaakt (85)

En wat de opstanding van Christus betreft: $z \mathrm{ij}$ is het hart van de prediking van de kerk en de kern van ons gelovig weten en zij moet een wonder blijven waarmee niets te vergelijken is $(85,89)$. Als kerkleden daarmee moeite hebben, moet de kerk met hen geduld 
hebben, zoals Christus dat met Thomas had. Maar de vraag wordt niet beantwoord: waarom is in de opstandingsverhalen niet het 'vergrootglas' gehanteerd?

6. Ik ben toegekomen aan de evaluatie.

(1) Als eerste opmerking zou ik willen stellen, dat de bijbel zelf geheel anders over de waarheid spreekt.

Christus noemt Zichzelf de waarheid, sprak woorden van waarheid en zond de Geest van de waarheid. Hij bad zijn Vader dat de discipelen in de waarheid zouden mogen blijven, dat is: zijn woord zouden mogen bewaren (Joh. 17).

De prediking van de apostelen wordt genoemd het woord der waarheid; die waarheid wordt in de prediking aan het licht gebracht.

En dat woord wordt tegengesproken, soms ook door de apostelen zelf (denk aan Paulus!). Niet door onze inzet wordt de waarheid kompleet, maar door onze gehoorzaamheid wordt de waarheid erkend. Wanneer wij aan de waarheid gehoorzaam zijn, zal die waarheid in ons zijn en zijn wij in de waarheid. Dan gaan wij dic waarhcid doen en wandelen op de weg van de waarheid.

En de bijbel maakt dat heel konkreet en tastbaar voor ons: de geboden van God zijn de waarheid. Daarom moeten én kunnen wij de waarheid gehoorzamen en de waarheid bewaren en de lendenen met de waarheid omgorden. Zo kan de kerk in de wereld een pijler en fundament van de waarheid zijn (1 Tim. $3: 15$ ).

Maar al deze gegevens van de Schrift zelf hebben in het rapport niet het eerste woord. De leer van de Schrift wordt niet vanuit de Schrift zelf opgebourwd.

(2) Het gezag van de Schrift ligt dan ook uitsluitend hierin, dat zij een inspirerend geschrift is voor ons. Maar zulke geschriften zijn er meer in de wereld!

(3) Het bijbellezen wordt op deze wijze gebracht onder de voogdij van de filosofie. Niet de filosofie van het rationalisme uit de $17 \mathrm{e}$ en $18 \mathrm{e}$ eeuw of van het positivisme uit de $19 \mathrm{e}$ eeuw of van het existentialisme uit de eerste helft van de $20 \mathrm{e}$ eeuw. Maar het bijbellezen komt nu onder voogdij van de eigentijdse filosofie: een communicatierideologie, waarin de waarheid ons zoekt en wij de waarheid zoeken en als we clkaar gevonden hebben, beginnen wij overnieuw. Want 'waarheid' is een eschatologisch begrip en het proces mag niet stilstaan, want anders stolt de waarheid en vervallen wij tot objektivisme.

Het is dan ook een verouderde filosofie, wanneer wij de historische betrouwbaarheid van het geschreven woord opvatten als: het is letterlijk gebeurd zoals het er staat (70). Dit is erg jammer voor Paulus, want die man ging nog wél van deze betrouwbaarheid uit, b.v. ten aanzien van de zondeval (Rom. 5; 2 Kor. 11; 1 Tim. 2).

(4) De opstanding van Christus kunnen wij slechts geloven vanwege het betrouwhare woord van de getuigen, inklusief Thomas. (Vgl. 1 Kor. 15-begin en 1 Joh. 1-begin). Dat woord is het enige woord dat de kerk daarover heeft. 
Maar dit getuigenis is niet het verslag van een belevenis, maar het rapport over gekonstateerde feiten.

Vanuit het rapport kunnen wij echter niet weerspreken de man, die zegt: deze getuigen geven hün geloofsinterpretatie van Jezus en zij kunnen deze interpretatie niet aan ons opleggen.

Kortom: het 'er staat geschreven' funktioneert niet meer. En juist $\mathrm{z} \delta$ heeft Christus zijn discipelen tot erkentenis van de waarheid gebracht (Luk. $24: 46$ ).

(5) De ethiek vindt geen houvast meer in duidelijke wilsbeschikkingen van God. Paulus was tenslotte ook maar een kultuurgebonden mens, met zijn verzet tegen homosexualiteit etc.

$\mathrm{Nu}$ zal de ethiek inderdaad te rekenen hebben met het onderscheid tussen de bedelingen. Maar intussen blijft de bijbel wél ons Gods wil over ons leven openbaren. De bijbel blijft daarom ook voortdurend allerlei moderne vormen van levensbesteding tegenspreken. Het rapport biedt mogelijkheden om aan die stem van de bijbel het zwijgen op te leggen.

(6) Volgens $h \epsilon^{\ddagger}$, rapport kennen wij God slechts in de vorm van een aantal godsbeelden, die geheel kultureel bepaald zijn. En wij zijn kinderen van onze kultuur. Zo schuift de waarheid door en met het menselijk geslacht mee. De waarheid is altijd 'onaf'.

Uiteindelijk komt dat hierop neer, dat wij in de bijbel toch eigenlijk alleen maar met ons voorgeslacht en met onszelf aan het spreken zijn. Want de bijbel is een "geloofsgetuigenis' en tenslotte zijn wijzelf het, die aan de bijbel voorzeggen wat zijn gezag zal zijn in déze tijd. God kan immers niet om ons heen, wanneer Hij tot ons spreken wil?

Hoe kan zo 'n bijbel ons ooit nog tegenspreken? Waar is hier de canon gebleven, waarnaar wij ons geloof richten, waarop wij het gronden en waarmee wij het bevestigen (art. 5 NGB)?

$\mathrm{Er}$ is hier maar één weerwoord: Koop waarheid en verkoopt ze niet (Spr. 23:23), nu de god van deze eeuw ons blind wil maken voor de waarheid die de apostelen in het evangelie aan het licht hebben gebracht (2 Kor. 4 ).

(7) Het is een goede zaak om de strijd aan te binden tegen het objektivisme, en het subjektivisme Wij mogen inderdaad niet objektivistisch met de bijbel omgaan.

Dan wordt de bijbel tot een verzameling uitspraken, die objektieve waarheden bevatten. Wij abstraheren de bijbel van de geschiedenis van het spreken en handelen van God en negeren de scopus daarvan. Wij maken de bijbel 'koud' en benutten hem slechts voor onze systeembouw. En dat is een verkapt rationalisme.

Wij mogen ook niet subjektivistisch met de bijbel omgaan. Dan trekken wij alles binnen de lichtkring van de menselijke beleving en leggen wij aan de bijbel een piëtistisch kriterium op.

Het is daarom volkomen terecht dat men boven het dilemma van subjektivisme en objektivisme wil uitkomen. Maar dat poogt men in deze tijd te doen met behulp van een communicatie-ideologie, waarin een humanistische filosofie verborgen zit. 
Daarom zullen wij deze ideologie slechts kunnen bestrijden vanuit een gezonde gereformeerde leer omtrent het verbond van God met de mens - een verbond van genade, dat door Jezus Christus is verdiend. In dat verbond heeft God het éerste woord en geeft $\mathrm{Hij}$ zichzelf een Naam. En wij worden daarin gereaktiveerd, wanneer wij ons eerst aan $Z i j n$ spreken in gehoorzaamheid gewonnen geven. 